\title{
Avifaunal Diversity of Institute of Forestry Complex, Hetauda Metropolis, Nepal
}

\author{
Santosh Bajagain ${ }^{*}$, Santosh Pokhrel ${ }^{2}$, Shishila Baniya ${ }^{3}$, Aavas Pradhan ${ }^{2}$, \\ Surakchya Paudel ${ }^{4}$ and Ishwar Datt Joshi ${ }^{4}$
}

\begin{abstract}
Avifaunal diversity is the measure of species diversity via species richness and evenness. To this aim, avifaunal survey was conducted in the Institute of Forestry Complex, Hetauda from November 2017 to June 2018. Using line transect and point count methods, 132 species of birds were recorded, representing 15 orders and 44 families. Three species of these birds are in IUCN Red List while 90, 27 and 15 species are residential, visitor and migrant respectively. Higher Shannon diversity index (4.47) and Margalef index (18.78) indicate marked diversity and richness of bird species. A high value calculated for the Simpson index (0.98) represents higher evenness within the species individuals. Although, Pielou's evenness index (0.92) shows uniformity in the species distribution, Shannon index seems to be influenced by diversity index, species richness and evenness values. The avifaunal diversity in the study area shows the importance of the Institute of Forestry Complex as a suitable bird habitat.
\end{abstract}

Key Words: Bird diversity, grassland habitat, point count, transect line, tropical forest, wetland habitat

Bajagain, S., S. Pokhrel, S. Baniya, A. Pradhan, S. Paudel, and I. Datt Joshi. 2020. Avifaunal Diversity of Institute of Forestry Complex, Hetauda Metropolis, Nepal. No. 17: page 83 to 101.

1 International Union for Conservation of Nature, Nepal

2 School of Forestry and Natural Resource Management, Institute of Forestry, Tribhuvan University, Kirtipur, Nepal

3 shishilabaniya@gmail.com

4 Tribhuvan University, Institute of Forestry, Hetauda Campus, Hetauda

* Corresponding Author, email: santosh bajagain@hotmail.com 


\section{Introduction}

Nepal is home to a plethora of avifauna with 886 species representing $9 \%$ of the world's avifaunal population (BCN 2020). Birds and their diversity constitute a main part of the natural ecosystem and have become a vital component of our environment (Basnet et al. 2016). Avifauna exhibit alteration in the habitat components and characteristics, thus indicating the quality of the forest landscape they inhabit (Moning and Müller 2008). Typical habitat has its own characteristics with regard to avifauna composition and any change in vegetation composition would alter the avifaunal community (Acevedo and Aide 2008). Several studies reveal that the structural characteristics of the habitat influence avifaunal diversity in general, and specific habitat preference in particular (Chakdar et al. 2016).

Forests of the Terai, Churia (Siwalik) and Bhabar range support a large number of avifauna species (Shrestha 2003). The foot hills of Nepal support half of the avifauna species found throughout the entire area of south Asia (Shrestha 2000). Under the National Park and Wildlife Conservation act, 1973, currently 9 species: Satyr Tragopan, Danphe, Cheer Pheasant, Great Hornbill, Bengal Florican, Lesser Florican, Sarus Crane, White Stork and Black Stork are protected species (Baral 2009) are under protection. Many other species which are not listed under this act, are of high importance and are not studied.

The IOF Complex is an urban forest/green space and wildlife refugium whose importance ramifies beyond the biodiversity value. Surrounded by human settlements on the north, east and south, the complex is under adverse anthropogenic pressure, thus underscoring urgent need for conservation action. In this context, the assessment of the bird community assemblage is a pre-requisite for understanding the population dynamics and their conservation significance. Although there have been several studies on urban forest bird dynamics in different parts of the country, the knowledge on bird assemblages in fast urbanizing city like Hetauda is scanty.

Despite a number of avian explorations by bird watchers, the information on species diversity, richness and assemblages at micro-landscape level in a given climatic regime is still missing from the region. The present study focuses on understanding the bird species richness, diversity and assemblages in the two different classified habitats, i.e., forested land and wetland associated with grassland habitat. This study was carried out to assess the difference in avian communities among these areas. It is initiation on making avifauna information of the IOF Complex up to date and will be helpful in preparing a baseline data on bird diversity.

\section{Materials and Methods}

\section{Study Site}

The study was carried out in IOF Complex (forest, grassland, hostel premises and staff quarter premises) and surrounding river and settlements at 433-450masl 
$\left(27^{\circ} 25^{\prime} 16^{\prime \prime} \mathrm{N}\right.$ and $\left.85^{\circ} 1^{\prime} 27^{\prime \prime} \mathrm{E}\right)$ of Hetauda Sub-metropolitan city, Makwanpur district (Figure 1). The study area lies in the lower tropical bioclimatic zone with tropical forest ecosystem. Vegetation type in the IOF Complex is under Lower Tropical Sal Forest (BPP 1995). The climate here is mild, and generally warm and temperate with average annual temperature of $22.7^{\circ} \mathrm{C}$. Summer receives more rainfall than winter with precipitation of about $2474 \mathrm{~mm}$ /year (CBS 2017). The study area is spread over an area of 97 hectare (using Garmin Etrex 10 and QGIS) and is surrounded by Mahendra Highway in the east, Karra river in the south, settlement area in north and Karra river and gravel road in the west. The area supports 98 butterflies (Chhetri 2017), 4 mammal and more than 150 floral species (Singh 2016). Mammals found include Spotted Deer (Axis axis), Rhesus Monkey (Macaca mulatta), Masked Palm, Civet (Pagumalarvata) and Indian Grey Mongoose (Herpestesedwardsi)(Pradhan et. al 2020). Out of the total area of the IOF Complex, 75.212 hectare belongs to forested area, 10.058 hectare belongs to grassland associated with wetland and remaining land is occupied by campus premises, nurseries and playground. Being surrounded by settlements in north, east and south, the study area faces immense anthropogenic pressure which includes poaching of the animals and collection of the forest products.

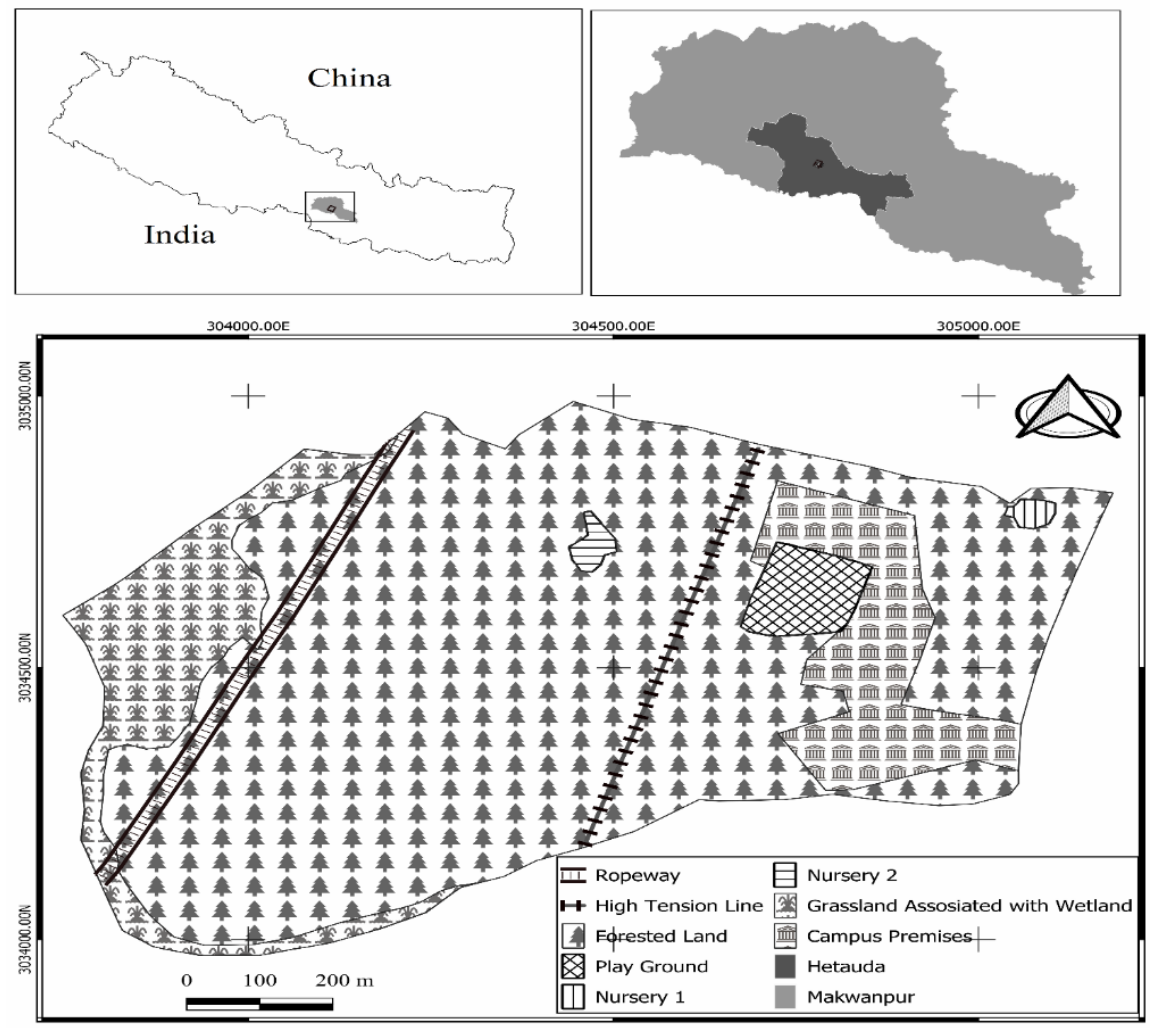

Figure 1: Geographical representation of study area 
For the data collection the entire study area was stratified into two broad habitat types:

\section{Forested Land}

The forested land is a Shorea robusta dominated forest along with other vegetations such as Terminalia tomentosa, Tectona grandis, Pinus roxburghii, Eucalyptus camaldulensis, Bombax ceiba, etc. This habitat type falls under Terai Tropical Sal Forest Ecosystem type (BPP 1995). It includes staff settlement area, open lands as well as forest areas which are close to human settlements in north-east part with less than $5^{\circ}$ slope and covers about $77.53 \%$ of the total area

\section{Grassland Associated with Wetland}

The grassland associated with wetland habitat (10.36 \% of the total area) belongs to riverine grassland ecosystem and water body ecosystem type (BPP 1995). Based on our field observation, this habitat type mainly includes natural mixed grass species such as Dactylorhiza hatagirea, Imperata cylindrica, Saccharum munja, Saccharum spontaneum, Stylosanthes guianensis, Achyranthes aspera and Arundo donax with, scattered tree species including Shorearobusta, Acacia catechu, Albizzia labbek, Bombax ceiba, Cassia fistula, Terminalia tomentosa, Madhuca indica and Dalbergia sissoo in the western part of study area and generally far from the human settlements. This habitat lies on south-west part of study area with evergreen vegetation and perennial water source.

\section{Study Methods}

The study was carried out between November 2017 and June 2018 for 16 days covering both the winter and summer season. A $500 \mathrm{~m}$ transect line with truncation distance of $50 \mathrm{~m}$ in existing trail was followed and birds in forward direction on both sides of the trail were recorded (Bibby et al. 2000). A total of 10 points count stations were systematically selected in each habitat type. A truncation distance of $50 \mathrm{~m}$ with point count duration of 10 minutes with a spacing rule of no points closer than $400 \mathrm{~m}$ to each other was considered (Bibby et al. 2000). To avoid the double counting, birds flying overhead were excluded, and the birds that flew from behind the observers were not recorded. The same route was followed in both seasons by recording the birds seen or heard (song/call) from 6:30 to 10:30 hrs when birds are active. The available birds were observed by naked eye and field binoculars $\left(8^{*} 42\right)$ and then bird species were identified and taxonomically classified using Birds of the Indian Subcontinent (Grimmett et al. 2016). Bird censuses were not carried out on rainy, windy and cloudy day to avoid biases due to change in intensity of bird activities.

\section{Data Analysis}

Bird checklists were meticulously maintained for both the habitats during the field visits. Obtained data were used to calculate various indices as explained below. 
Species diversity of the documented birds was analyzed using the diversity indices. The widely used diversity indices are Shannon diversity index (H) (Shannon 1948), Simpson diversity index (D) (Simpson 1949), Whereas to understand the species richness Pielou's evenness index, Margalef Index: were used

Shannon index $(\mathrm{H})=\mathrm{H}^{\prime}=-\sum \mathrm{p}_{\mathrm{i}} \ln \mathrm{p}_{\mathrm{i}}$ equation (1)

Where "pi" is the proportion of $(\mathrm{n} / \mathrm{N})$ of individuals of one particular species found (n) divided by total number of individuals found $(\mathrm{N})$, " $\ln$ " natural $\log , \mathrm{E}$ is the sum of calculation and $s$ is the number of species.

Simpson's index is based on the probability of any two individuals drawn at random from an infinitely large community belonging to the same species:

$\mathrm{D}=\sum \mathrm{pi}^{2}$ equation (2)

Where again pi is the proportion of individuals found in species i. For a finite community, this is $\mathrm{D}=\sum\left[\mathrm{n}_{\mathrm{i}}\left(\mathrm{n}_{\mathrm{i}}-1\right) / \mathrm{N}(\mathrm{N}-1)\right.$ equation (3)

Here $\mathrm{D}$ is a measure of dominance, so as D increases, diversity (in the sense of evenness) decreases. Thus, Simpson's index is usually reported as its complement 1D (Somerfield et al. 2008)

Margalef Index: This index is used for small samples. It can be measured as:

$\mathrm{H}=\mathrm{S}-1 / \mathrm{InN}$ equation (4)

Here,

$\mathrm{H}=$ Margalef's index

$\mathrm{S}=$ Number of species

$\mathrm{N}=$ Total number of individuals

Pielou's evenness index $(\mathrm{J})=\mathrm{H} / \mathrm{H} \max$ equation (5)

Here,

$\mathrm{H}=$ Shannon-Weaver index

Hmax $=$ Maximum value of $\mathrm{H} . \mathrm{Hmax}=\ln \mathrm{S}$

The mathematical calculation was done using "vegan" package (Oksanen 2013) in R.

\section{Results and Discussion}

\section{Results}

Avian species composition and population in two different habitats 
The present study documented the presence of 1202 individuals of avifauna belonging to 132 species, 15 orders and 44 families in the study area (Refer annex I). In forested habitat 697 individuals belonging to 81 species, 35 families and 12 orders were documented. Similarly, in wetland associated with grassland 505 individuals belonging to 80 species, 35 families and 13 orders were documented. A total of 29 species belonging to 15 families and 6 orders were recorded in both habitats (Table $1)$.

\section{Table 1: Population and composition of avifauna in different habitat of IOF} Complex

\begin{tabular}{|l|l|l|l|l|l|l|l|l|}
\hline \multirow{2}{*}{ Habitat } & \multicolumn{2}{|c|}{ Individuals } & \multicolumn{2}{c|}{ Species } & \multicolumn{2}{c|}{ Family } & \multicolumn{2}{c|}{ Order } \\
\cline { 2 - 9 } & Count & $\begin{array}{c}\text { Population } \\
(\%)\end{array}$ & Count & $\begin{array}{c}\text { Population } \\
(\%)\end{array}$ & Count & $\begin{array}{c}\text { Population } \\
(\%)\end{array}$ & Count & $\begin{array}{c}\text { Population } \\
(\%)\end{array}$ \\
\hline $\begin{array}{l}\text { Forested } \\
\text { land }\end{array}$ & 697 & 57.99 & 81 & 61.36 & 31 & 70.45 & 12 & 80.00 \\
\hline $\begin{array}{l}\text { Wetland \& } \\
\text { Grassland }\end{array}$ & 505 & 42.01 & 80 & 60.61 & 33 & 75.00 & 13 & 86.67 \\
\hline Both & 549 & 45.67 & 29 & 21.97 & 15 & 34.09 & 6 & 40.00 \\
\hline
\end{tabular}

The Passeriformes is the dominant order documented in both habitats. The population of 18 species belonging to it in both habitat accounts for $33 \%$ of total population followed by Psittaciformes $(3$ species $=6.24 \%)$, Strigiformes $(4$ species $=$ $2.16 \%)$, Columbiformes ( 1 species $=1.83 \%$ ) and Charadriiformes $(1$ species $=1.25 \%$ ). Whereas, Camephagidae, Caraciidae, Cisticolidae, Columbidae, Corvidae, Dicruridae, Glareolidae, Hirundinidae, Meropidae, Muscipdae, Pariade, Psittacidae, Pycononotidae, Strigidae and Sturnidae were common families observed in both the habitats.

In forested habitat Jungle babbler was found to have the highest population $(34=4.88 \%)$ followed by Red vented bulbul $(27=3.87 \%)$, Great tit $(25=3.59 \%)$, House sparrow $(24=3.44 \%)$, Alexandrine parakeet $(24=3.44 \%)$ and Rufous treepie $(23=3.305 \%)$. The average mean population of the species was 8.65 individuals while the median value was 6 (Figure 2(a)).Likewise, in wetland associated with grassland, Common tailor bird $(24=4.75 \%)$, Asian open bill $(21=4.16 \%)$, Red-vented bulbul $(20=3.96 \%)$, Common myna $(18=3.56 \%)$ and House crow $(17=3.37 \%)$ were dominant species. The average mean population of the species was 6 individuals while the median value was 5 .

The species population in IOF range from 1 to 47 individuals. Red-vented bulbul was found to have highest number of individuals (47 individuals), which accounts for $3.91 \%$ of total population followed by House crow and Alexandrine parakeet with 38 individuals representing $3.16 \%$ of total population. The average species population was found to be 9 with median value of 6 (Figure 2(a)). 
2(a)

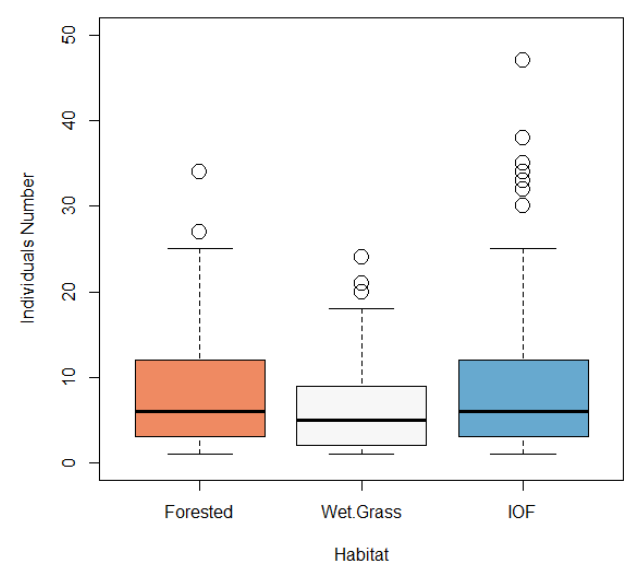

2(b)

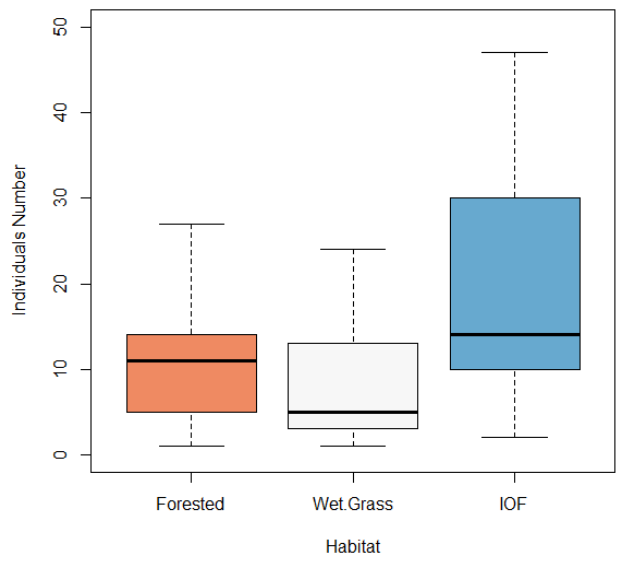

Figure 2: (a) Population of individuals in different habitats (b) Population of common individuals in different habitats

The box plot (Figure 2(b)) demonstrated the asymmetrical distribution of the common species population. The population of commonly observed species ranges from 1-27 and 1-24 in forested and wetland associated with grassland. The average mean population and median value were 10.79 and 11 in forested habitat while it was and 8.13, and 5 in wetland associated with grassland.

The maximum population of common species individuals of IOF was 47 which represent the Red vented bulbul species while minimum was 2 individuals. Among the common species, Red-vented bulbul (47) were found to have the highest population followed by Alexandrine parakeet (38) and House crow (38). Asian barred owlet has lowest population of 2 individuals.

\section{Avian Species Diversity Indices}

Table 2 gives the comparative diversity indices of avifauna in different habitats. The Shannon diversity index of IOF Complex was found to be 4.47. Species diversity of wetland associated with grassland 4.08 is slightly greater than forested land with 4.06. This means both habitats are rich in avifaunal diversity. The Simpson diversity index value is the same 0.98 for both the habitats. Similarly, Pielou's evenness index value 0.92 shows no variance along the habitats. This means lower disparity within the species individual populations. The Margalef species richness value for IOF Complex was found to be 18.78. This was slightly higher in wetland associated with grassland (13.34) than in forested land (12.62). 
Table 2: Comparative Diversity indices of avifauna in different habitat of IOF

\begin{tabular}{|l|l|l|l|}
\hline \multirow{2}{*}{ Diversity Indices } & \multicolumn{3}{|c|}{ Habitat } \\
\cline { 2 - 4 } & Forested land & $\begin{array}{c}\text { Wetland \& } \\
\text { Grassland }\end{array}$ & IOF Complex \\
\hline Shannon index & 4.06 & 4.08 & 4.47 \\
\hline Fisher alpha index & 23.72880 & 26.76332 & 37.82501 \\
\hline Simpson diversity index & 0.98 & 0.98 & 0.98 \\
\hline Pielou's evenness index (j) & 0.92 & 0.92 & 0.92 \\
\hline Richness in terms of number & 81 & 80 & 132 \\
\hline Margalef index (D) & 12.62 & 13.34 & 18.78 \\
\hline
\end{tabular}

\section{Migratory Status of Avifauna in Study Area}

A total of 90 residential species make up $77 \%$ of total population in study area. The visitors and migratory species represent 27 and 15 species, which account for the $15 \%$ and $8 \%$ of total population respectively (Figure $3(\mathrm{a})$ and $3(\mathrm{~b})$ ).

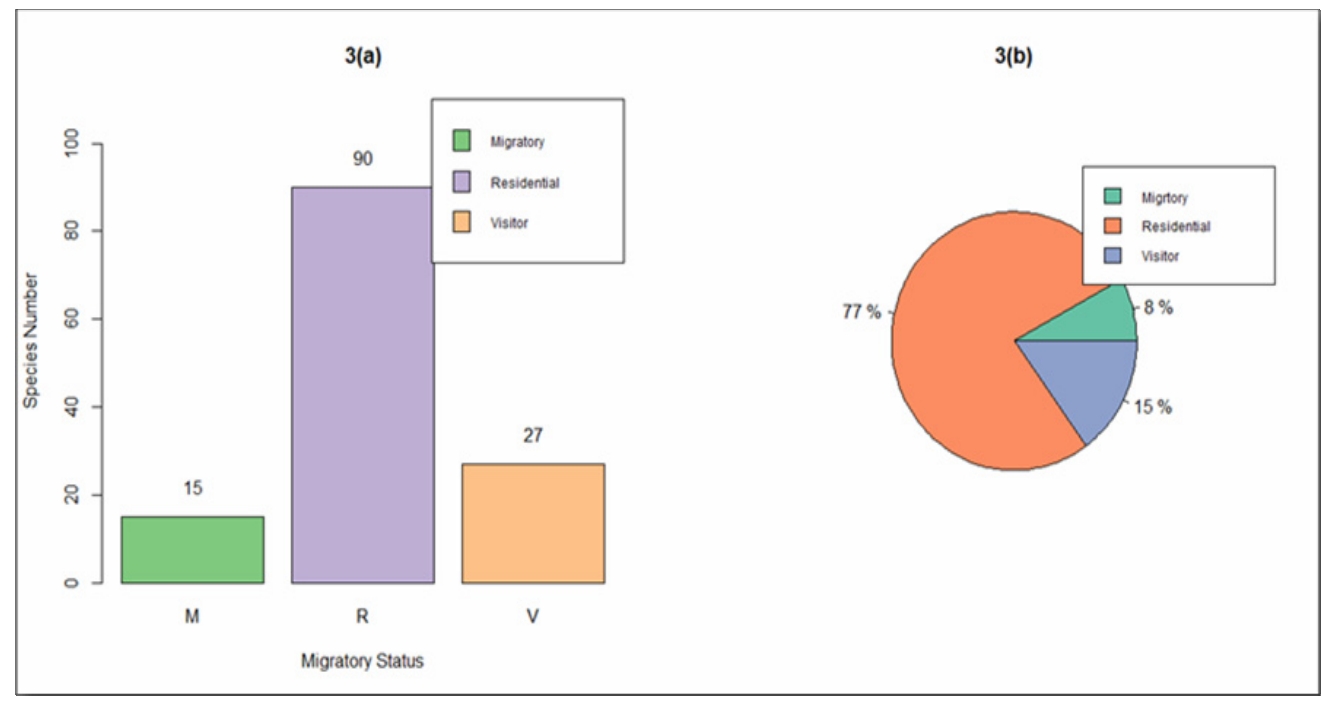

Figure 3: (a) Migration status of avifauna in IOF Complex, (b) Population proportion of avifauna with its migratory status( $M=$ migratory=Residential, V=visitor)

In case of migratory species, Small pratincole (15) followed by Cattle egret (14), Rosy pipit (14) and visitor species like Plump headed parakeet (25) were found to have high individual population. 
Table 3: Comparative migratory status of avifauna documented in IOF Complex

\begin{tabular}{|l|l|l|l|l|}
\hline \multirow{2}{*}{$\begin{array}{l}\text { Migratory } \\
\text { Status }\end{array}$} & \multicolumn{3}{|l|}{ Forested habitat } & Wetland \& grassland habitat \\
\cline { 2 - 5 } & Count & $\begin{array}{l}\text { Population } \\
\text { proportion (\%) }\end{array}$ & Count & $\begin{array}{l}\text { Population } \\
\text { proportion (\%) }\end{array}$ \\
\hline Migratory & 14.00 & 1.16 & 83.00 & 6.91 \\
\hline Residential & 555.00 & 46.17 & 370.00 & 30.78 \\
\hline Visitor & 128.00 & 10.65 & 52.00 & 4.33 \\
\hline
\end{tabular}

Wetland associated with grassland has comparatively higher number of migratory and residential individuals. The visitor individuals are high in wetland associated with grassland.

Table 4: Migratory status and population distribution of threatened avian species

\begin{tabular}{|l|l|l|l|l|l|l|}
\hline \multirow{3}{*}{ Status } & \multicolumn{4}{|c|}{ Habitat } & \multicolumn{2}{c|}{ Population in \% } \\
\cline { 2 - 5 } \cline { 3 - 4 } & \multicolumn{3}{|c|}{$\begin{array}{c}\text { Within } \\
\text { nationally } \\
\text { threatened } \\
\text { individuals }\end{array}$} & $\begin{array}{c}\text { \% within } \\
\text { total } \\
\text { population }\end{array}$ \\
\cline { 2 - 5 } & Total & $\%$ & Total & $\%$ & & \\
\hline Residential & 12.00 & 85.71 & 21.00 & 70.00 & 28.21 & 2.75 \\
\hline Visitor & 2.00 & 14.29 & 9.00 & 30.00 & 9.40 & 0.92 \\
\hline
\end{tabular}

The population of nationally threatened species population is composed of $28.21 \%$ of residential and $9.40 \%$ of visitor individuals. This also accounts for $2.75 \%$ and $0.92 \%$ of total population of residential and visitors respectively. On comparing the migratory status of these individuals in two different habitats, residential species population was found to be higher in both forested land $(85.71 \%)$ and wetland associated with grass land $(70.00 \%)$ followed by visitor individuals. None of the species reordered under migratory species were listed under threatened status (Table $4)$.

\section{Threatened Species Population Composition and Conservation Status}

Out of 132 species, only Steppe eagle is recognized as threatened species by International Union for Conservation of Nature (IUCN) Red data book. Its global status is endangered while it is listed as vulnerable under National status. It was only observed in wetland associated with grassland and accounts for $0.50 \%$ of total population. However, additional 2 species (Table 5) are recognized as threaten species under national status. 
Table 5: Threatened species recorded in IOF Complex

\begin{tabular}{|l|l|l|l|l|l|l|l|l|}
\hline \multirow{2}{*}{$\begin{array}{l}\text { S. } \\
\text { N }\end{array}$} & \multirow{2}{*}{ Common Name } & Scientific Name & \multicolumn{2}{|l|}{ Habitat } & \multicolumn{2}{l|}{ Threatened Status } & \multirow{2}{*}{$\begin{array}{l}\text { Migratory } \\
\text { Status }\end{array}$} \\
\cline { 4 - 11 } & & Forested & $\begin{array}{l}\text { Wet/ } \\
\text { Grass }\end{array}$ & IOF & Global & National & \\
\hline 1 & Asian openbill & Anastomus oscitans & 12 & 21 & 33 & LC & VU & R \\
\hline 2 & Brown fish-owl & Ketupa zeylonensis & 2 & 1 & 3 & LC & VU & V \\
\hline 3 & Steppe eagle & Aquila nipalensis & 0 & 6 & 6 & EN & VU & V \\
\hline
\end{tabular}

Note: LC=Least Concern, EN=Endangered, NT=Near Threatened, VU=Vulnerable (DNPWC 2018; Inskipp et al., 2017)

All 3 species shared vulnerable threatened status (Table 5). These 42 individuals of nationally threatened species population account for $3.49 \%$ of total population in the study area. Threatened species population is higher in wetland associated with grassland than in forested land.

\section{Discussion}

Knowledge on species composition of avifauna from unprotected habitats is crucial to understand the health of the environment and to develop effective and sustainable bird conservation strategies and management measures (Kiros et al. 2018). The study area is habitat to $14.90 \%$ of 886 bird species documented in Nepal (DNPWC 2018). None of the threatened species documented in this area falls under the protected species list (Baral 2009). Species under Corvidae family of Passeriformes order were dominant in both the habitats. This result also aligns with a study in Khata corridor (Chaudhari et al. 2009).

The Shannon index value (4.47) indicates that IOF complex has rich avifaunal diversity. This index value was normally noted between 1.5 and 3.5 and rarely exceeded above 4.5 (Gaines 1999). Similar Shannon index value, 4.33 was also obtained in degraded forest while studying tree species diversity in Congo (Ifo et al. 2016). This index is used to assess uncertainty of the species or to know how diverse is certain community (Ortiz-Burgos 2016). Higher uncertainty means rich in diversity. The Shannon index is influenced by species richness and evenness values (Yeom and Kim 2011; Supriatna 2018) where both indices are biased towards richness of rare and dominant species respectively (Winfree et al. 2015; Goudarzian and Erfanifard 2017). The population distribution of species unique to each habitat is symmetrical but it is asymmetrical with population of 29 common species (Table 1). This population might have influenced the result. In our study, high diversity (4.08) was documented in wetland associated with grassland habitat with 80 species while the same index value was 4.06 in forested habitat with 81 species (Table 1 and 2).

The positive association between the species richness and heterogeneous habitat supports diverse species (Basnet et al. 2016). The study area comprises of heterogeneous habitat; both forested and wetland habitats associated with grassland 
are adjacent to each other. This heterogeneity in habitat could be a possible explanation of diverse species (Berg 1997). However, the higher number of the species alone is not enough to conclude high diversity (Spellerberg and Fedor 2003). We further used Simpson index which range from 0-1 where 0 represents no diversity and 1 represents high diversity (Oksanen et al. 2013). Pielou's evenness index (j) was used to understand how species population is distributed within the community. Skewedness of (J) value toward 1 suggests uniformity in species population distribution and richness in diversity (Heip et al. 1998). Margalef Index used to evaluate the species richness (Magurran 2004) also supports conclusion of Shannon index result; area is rich in avifaunal diversity.

Previous studies recorded that the species richness varies with altitude, forest edge, canopy coverage and slope (Hunter and Yonzon 1993; Ghimire 2015). Additionally, species richness is also influenced by habitat heterogeneity, volume of certain tree species (Berg 1997; Acharya et al. 2011) and seasons (Katuwal et al. 2016). According to Basnet et al. (2016) previously mentioned factors are responsible for the distribution of the species populations rather than species richness. Similarly, bird population, bird species richness was recorded higher in farmland and fresh water but evenness was not affected (Hung-Ming et al. 2020).

The threatened species richness in general is negatively correlated with elevation and positively correlated with human settlement (Paudel et al. 2018). The numbers of recorded threatened species and their population are comparatively less than what is mentioned in previous studies. Though the number per unit area is comparatively less, it is a preserved habitat and urban refugia for academic purpose. Studies have shown that the riverine and grassland moist forests were recorded to have high number of threatened species and individuals' number was higher in Khair-Sissoo forest in Khata corridor (Chaudhari et al. 2009). Our study shows high population of nationally threatened species in wetland associated with grassland (Table 4). Species with residential migratory status were higher in unique species number and in total individual population (Figure 3(a) and 3(b)).

In Nepal $95.73 \%$ of avifaunal diversity are documented within the protected areas. According to Dahal et al. (2014), out of 124 bird species of low land, Nepal, 24\% were recorded in forest outside the protected area and $45 \%$ of species were common to the protected area, community-based forest area and national forest. Even though protected area is home to global biodiversity, off-reserve area is also equally significant for conserving biodiversity (Dahal et al. 2014).

\section{Conclusion}

The IOF Complex is a remnant forest area that is home to diverse bird communities. The high value of the Shannon index (4.47) is an indication of richness of avifaunal diversity in the area. Other measured indices and observation reveal that the study area supports diversified species in heterogeneous habitat. The study area supports fairly high bird diversity with a total of 132 species distributed in 15 orders and 44 
families. Identification of 90 residential species representing $77 \%$ of total birds along with three species of IUCN Red listed species warrants further research and exploration of the IOF Complex. Although, the IOF Complex is less jeopardized with threats such as habitat conversion and hunting, current infrastructures that are being built may deplete the breeding and feeding ground of the avifauna and will affect the bird diversity. Hence, developmental activities like road and building construction should be sensitive to biodiversity conservation, if unavoidable should be confined away from prime forests, wetland and grassland habitats.

\section{Acknowledgement}

Institute of Forestry, Hetauda Campus is gratefully acknowledged for granting the permission and necessary support for this study. We are thankful to Dr. Menuka Maharjan, Mr. Bikram Manandhar, Mr. Dol Raj Thanet and Mr. Raghu Nath Lal Karn, faculty members of IOF Hetauda, for their constant support and guidance throughout the study period. Thanks to Mr. Bikram Singh, Mr. Padam Prakash Jaishi, Mr. Ashish Neupane, Mr. Nishan Bhandari and Mr. Kasip Tiwari for supporting in field activities.

\section{Literature Cited}

Acevedo, M. A., and T. M. Aide. 2008. Bird community dynamics and habitat associations in karst, mangrove and Pterocarpus forest fragments in an urban zone in Puerto Rico. Caribbean Journal of Science. 44(3):402-416.

Acharya, B. K., N. J. Sanders, L. Vijayan, and B. Chettri. 2011. Elevational gradients in bird diversity in the Eastern Himalaya: an evaluation of distribution patterns and their underlying mechanisms. PloS one. 6(12), p.e29097.

Baral, H. S. 2009. Updated Status of Nepal's Wetland Birds. Banko Janakari, Special Issue. 30-35.

Basnet, T. B., M. B. Rokaya, B. P. Bhattarai, and Z. Münzbergová. 2016. Heterogeneous landscapes on steep slopes at low altitudes as hotspots of bird diversity in a Hilly Region of Nepal in the Central Himalayas. PloS one. 11(3), p.e0150498.

Berg, Å. 1997. Diversity and abundance of birds in relation to forest fragmentation, habitat quality and heterogeneity. Bird study. 44(3):355-366.

Bibby, C., M. Jones, and S. Marsden. 2000. Expedition Field Techniques: Bird Surveys. BirdLife International.

BPP. 1995. Biodiversity Profile of the Terai/Siwalik Physiographic Zones. In Biodiversity Profile Project, Publication No. 12. Kathmandu: GoN Department of National Parks and Wildlife Conservation.

Bird Conservation Nepal. 2020. Birds of Nepal. Available online at Http://Www.Birdlifenepal.Org/Birds/Status-of-Birds; last accessed July 5, 2020. 
Chakdar, B., P. Choudhury, and H. Singha. 2016. Avifaunal diversity in Assam University Capmus, Silchar, India. Journal of Threatened Taxa. 8(1):8369-8378.

Chaudhari, U. K., G. Kafle, and H.S. Baral. 2009. Avifaunal diversity of khata corridor forest. Journal of Wetlands Ecology. 2:48-56.

Chhetri, S. 2017. Status and Distribution of Butterfly. A Case Study from Institute of Forestry, Hetauda, Nepal. M.Sc. thesis, Tribhuvan University., Nepal. 19p.

Dahal, B. R., C. A. McAlpine, and M. Maron. 2014. Bird conservation values of offreserve forests in lowland Nepal. Forest Ecology and Management. 323:28-38.

DNPWC; BCN. 2018. Birds of Nepal: An Official Checklist. Department of National Parks and Wildlife Conservation and Bird Conservation Kathmandu, Nepal.

Gaines, W.L. 1999. Monitoring biodiversity: quantification and interpretation. US Department of Agriculture, Forest Service, Pacific Northwest Research Station. 25p.

Ghimire, A. 2015. Bird diversity along an elevational gradient in the Manang District, Central Nepal. PhD thesis, Tribhuvan University., Nepal. 6p.

Goudarzian, P., and S. Y. Erfanifard. 2017. The efficiency of indices of richness, evenness and biodiversity in the investigation of species diversity changes (case study: migratory water birds of Parishan international wetland, Fars province, Iran). Biodiversity International Journal.1 (2):41-45.

Grimmett, R., C. Inskipp, and T. Inskipp. 2016. Birds of the Indian Subcontinent: India, Pakistan, Sri Lanka, Nepal, Bhutan, Bangladesh and the Maldives. Bloomsbury Publishing.

Heip, C. H., P. M. Herman, and K. Soetaert. 1998. Indices of diversity and evenness. Oceanis. 24 (4):61-88.

Tu, H. M., M. W. Fan, and J. C. J. Ko. 2020. Different Habitat Types Affect Bird Richness and Evenness. Scientific reports. 10(1):1-10.

Hunter, M. L, and P. Yonzon. 1993. Altitudinal distributions of birds, mammals, people, forests, and parks in Nepal. Conservation Biology. 7(2):420-423.

Ifo, S. A., J. M. Moutsambote, F. Koubouana, J. Yoka, S F. Ndzai, L.N.O. BouetouKadilamio, H. Mampouya et al. 2016. Tree species diversity, richness, and similarity in intact and degraded forest in the tropical rainforest of the Congo Basin: case of the forest of Likouala in the Republic of Congo. International Journal of Forestry Research. 2016.

Inskipp, C., H. S. Baral., T. Inskipp, A. P. Khatiwada, M. P. Khatiwada, L. P. Poudyal, and R. Amin. 2017. Nepalâ€ $€^{\mathrm{TM}}$ s National Red List of Birds. Journal of Threatened Taxa. 9(1):9700-9722.

Katuwal, H. B., K. Basnet, B. Khanal, S. Devkota, S. k. Rai, J. P. Gajurel, C. Scheidegger et al. 2016. Seasonal changes in bird species and feeding guilds along elevational gradients of the Central Himalayas, Nepal. PLoS One. 11(7): p.e0158362. 
Magurran, A. E. 2004. Measuring Biological Diversity. Oxford: Blackwell Publishing. $256 \mathrm{p}$.

Moning, C., and J. Müller. 2008. Environmental key factors and their thresholds for the avifauna of temperate montane forests. Forest Ecology and Management. 256(5):1198-1208.

Oksanen, J. 2013. Vegan: ecological diversity. R Project.

Oksanen, J., F. G. Blanchet, R. Kindt, P. Legendre, P. R. Minchin, R. B. O'hara, G. L. Simpson et al. 2013. Community ecology package. $R$ package version. 2 (9):1-295.

Ortiz-Burgos, S. 2016. Shannon-weaver diversity index. In Encyclopedia of Estuaries: 572-573. Springer Netherlands.

Paudel, P.K., J. Sipos, and J.F. Brodie. 2018. Threatened species richness along a Himalayan elevational gradient: quantifying the influences of human population density, range size, and geometric constraints. BMC ecology. p6.

Pradhan, A., S. Bajagain, and R. Sedhain. 2020. Checklist of Serpents in Institute of Forestry, Hetauda Campus Complex, Makwanpur, Nepal. The Himalayan Naturalist 3(1):16-19.

Rural Municipality/Municipality Profile, Makwanpur. 2017. Statistics Office, Makwanpur, Nepal.: Central Bureau of Statistics.

Shannon, Claude E. 1948. A Mathematical Theory of Communication. The Bell System Technical Journal. 27 (3):379-423.

Shrestha, T. K. 2000. Birds of Nepal:field ecology, natural history, and conservation: with reference to those of India, Bangladesh, Bhutan, Pakistan, and Sri Lanka: photographic field guide (Vol. 1). Steven Simpson Books.

Shrestha, T. K. 2003. Birds of Nepal. Field Ecology, Natural History and Conservation. Vol. 1. R.K Printers, Kathmandu, Nepal.

Simpson, E. H. 1949. Measurement of diversity Nature. London. p4148.

Singh, B. K. 2016. An Assessment of Biomass and Carbon Stock in Tropical Natural Forest of Nepal(A Case Study of Institute of Forestry Hetauda Campus). B.Sc. thesis, Tribhuvan University, Nepal. 22p.

Somerfield, P.J., K.R. Clarke, and R.M. Warwick. 2008. Simpson index. Elsevier.

Spellerberg, I.F., and P.J. Fedor. 2003. A tribute to Claude Shannon (1916-2001) and a plea for more rigorous use of species richness, species diversity and the 'Shannon-Wiener' Index. Global ecology and biogeography. 12(3):177-179.

Supriatna, J. 2018. Biodiversity Indexes: Value and Evaluation Purposes. In E3S Web of Conferences. 48:01001.

Winfree, R., J.W. Fox, N.M. Williams, J.R. Reilly, and D.P. Cariveau. 2015. Abundance of common species, not species richness, drives delivery of a real world ecosystem service. Ecology letters. 18(7):626-635. 
Yeom, D.J., and J.H. Kim. 2011. Comparative evaluation of species diversity indices in the natural deciduous forest of Mt. Joembong. Forest Science and Technology. 7(2):68-74.

\section{Annex: Species Inventory}

\begin{tabular}{|c|c|c|c|c|c|c|}
\hline $\begin{array}{l}\mathrm{S} \\
\mathrm{N}\end{array}$ & Common Name & Scientific Name & $\begin{array}{l}\text { Forested } \\
\text { land }\end{array}$ & $\begin{array}{l}\text { Wetland/ } \\
\text { Grassland }\end{array}$ & $\begin{array}{l}\text { IUCN } \\
\text { Status }\end{array}$ & $\begin{array}{l}\text { Migratory } \\
\text { Status }\end{array}$ \\
\hline 1 & $\begin{array}{l}\text { Alexandrine } \\
\text { parakeet }\end{array}$ & Psittaculaeupatria & $\checkmark$ & $\checkmark$ & - & $\mathrm{R}$ \\
\hline 2 & Ashy drongo & Dicrurusleucophaeus & $\checkmark$ & $\checkmark$ & - & $\mathrm{R}$ \\
\hline 3 & Ashy prinia & Priniasocialis & - & $\checkmark$ & - & $\mathrm{R}$ \\
\hline 4 & Asian barred owlet & Glaucidium cuculoides & $\checkmark$ & $\checkmark$ & - & $\mathrm{R}$ \\
\hline 5 & Asian koel & Eudyna mysscolopaceus & $\checkmark$ & - & - & V \\
\hline 6 & Asian openbill & Anastomus oscitans & $\checkmark$ & $\checkmark$ & LC & $\mathrm{R}$ \\
\hline 7 & Asian pied starling & Sturnus contra & $\checkmark$ & $\checkmark$ & - & $\mathrm{R}$ \\
\hline 8 & Barn swallow & Hirundorustica & - & $\checkmark$ & - & $\mathrm{R}$ \\
\hline 9 & Black bulbul & Hypsipetes leucocephalus & $\checkmark$ & $\checkmark$ & - & $\mathrm{R}$ \\
\hline 10 & Black drongo & Dicrurus macrocercus & $\checkmark$ & $\checkmark$ & - & $\mathrm{R}$ \\
\hline 11 & Black hooded oriole & Oriolus xanthornus & $\checkmark$ & - & - & $\mathrm{R}$ \\
\hline 12 & Black kite & Milvus migrans & $\checkmark$ & - & - & $\mathrm{R}$ \\
\hline 13 & Black lored tit & Parus xanthogenys & $\checkmark$ & $\checkmark$ & - & $\mathrm{R}$ \\
\hline 14 & $\begin{array}{l}\text { Blue- beared bee- } \\
\text { eater }\end{array}$ & Nyctyornisathertoni & - & $\checkmark$ & - & $\mathrm{V}$ \\
\hline 15 & $\begin{array}{l}\text { Blue-tailed bee- } \\
\text { eater }\end{array}$ & Merops philippinus & $\checkmark$ & $\checkmark$ & - & $\mathrm{V}$ \\
\hline 16 & $\begin{array}{l}\text { Blue-throated } \\
\text { barbet }\end{array}$ & Megalaima asiatica & $\checkmark$ & - & - & $\mathrm{R}$ \\
\hline 17 & Brahminy starling & Sturnus pagodarum & $\checkmark$ & $\checkmark$ & - & $\mathrm{V}$ \\
\hline 18 & Brown fish-owl & Ketupa zeylonensis & $\checkmark$ & $\checkmark$ & LC & $\mathrm{V}$ \\
\hline 19 & $\begin{array}{l}\text { Brown headed } \\
\text { barbet }\end{array}$ & Megalaima zeylanica & $\checkmark$ & - & - & V \\
\hline 20 & $\begin{array}{l}\text { Brown-capped } \\
\text { pigmy woodpecker }\end{array}$ & Dendrocopos nanus & $\checkmark$ & - & - & $\mathrm{V}$ \\
\hline 21 & Cattle egret & Bubulcus ibis & - & $\checkmark$ & - & $\mathrm{M}$ \\
\hline 22 & $\begin{array}{l}\text { Chestnut-headed } \\
\text { bee-eater }\end{array}$ & Merops leschenaulti & - & $\checkmark$ & - & $\mathrm{V}$ \\
\hline 23 & $\begin{array}{l}\text { Common hawk } \\
\text { cuckoo }\end{array}$ & Hierococcyx varius & $\checkmark$ & - & - & $\mathrm{R}$ \\
\hline 24 & Common hill myna & Gracula religiosa & $\checkmark$ & $\checkmark$ & - & $\mathrm{V}$ \\
\hline
\end{tabular}




\begin{tabular}{|c|c|c|c|c|c|c|}
\hline 25 & Common hoppoe & Upupa epops & - & $\checkmark$ & - & $\mathrm{V}$ \\
\hline 26 & Common iora & Aegithina tiphia & - & $\checkmark$ & - & $\mathrm{R}$ \\
\hline 27 & Common kingfisher & Alcedo atthis & - & $\checkmark$ & - & $\mathrm{R}$ \\
\hline 28 & Common myna & Acridotheres tristis & $\checkmark$ & $\checkmark$ & - & $\mathrm{R}$ \\
\hline 29 & Common pigeon & Columba livia & $\checkmark$ & - & - & $\mathrm{R}$ \\
\hline 30 & Common sandpiper & Actitis hypoleucos & - & $\checkmark$ & - & $\mathrm{M}$ \\
\hline 31 & Common stonechat & Saxicola torquatus & - & $\checkmark$ & - & $\mathrm{R}$ \\
\hline 32 & Common tailor bird & Orthotomus sutorius & $\checkmark$ & $\checkmark$ & - & $\mathrm{R}$ \\
\hline 33 & $\begin{array}{l}\text { Common } \\
\text { woodshrike }\end{array}$ & Tephrodornis pondiceranus & - & $\checkmark$ & - & $\mathrm{R}$ \\
\hline 34 & Coppersmith barbet & Megalaima haemacephala & $\checkmark$ & - & - & $\mathrm{R}$ \\
\hline 35 & $\begin{array}{l}\text { Crested serpent } \\
\text { eagle }\end{array}$ & Spilornis cheela & $\checkmark$ & - & - & $\mathrm{R}$ \\
\hline 36 & $\begin{array}{l}\text { Eurasian collard } \\
\text { dove }\end{array}$ & Stigmatopelia decaocto & $\checkmark$ & - & - & $\mathrm{M}$ \\
\hline 37 & Eurasian cuckoo & Cuculus canorus & $\checkmark$ & - & - & $\mathrm{V}$ \\
\hline 38 & $\begin{array}{l}\text { Eurasian tree } \\
\text { sparrow }\end{array}$ & Passer montanus & $\checkmark$ & - & - & $\mathrm{R}$ \\
\hline 39 & $\begin{array}{l}\text { Fulvous-breasted } \\
\text { woodpecker }\end{array}$ & Dendrocopos macei & $\checkmark$ & - & - & $\mathrm{R}$ \\
\hline 40 & $\begin{array}{l}\text { Golden-fronted } \\
\text { leafbird }\end{array}$ & Chloropsis aurifrons & $\checkmark$ & - & - & $\mathrm{V}$ \\
\hline 41 & Great barbet & Megalaima virens & $\checkmark$ & - & - & $\mathrm{V}$ \\
\hline 42 & Great egret & Ardea alba & - & $\checkmark$ & - & $\mathrm{M}$ \\
\hline 43 & Great tit & Parus major & $\checkmark$ & $\checkmark$ & - & $\mathrm{R}$ \\
\hline 44 & Greater coucal & Centropus sinensis & $\checkmark$ & - & - & $\mathrm{R}$ \\
\hline 45 & Greater flameback & Chrysocolaptes lucidus & $\checkmark$ & - & - & $\mathrm{R}$ \\
\hline 46 & $\begin{array}{l}\text { Greater racket } \\
\text { tailed drongo }\end{array}$ & Dicrurus paradiseus & $\checkmark$ & - & - & $\mathrm{R}$ \\
\hline 47 & Greater yellownape & Picus flavinucha & $\checkmark$ & - & - & $\mathrm{R}$ \\
\hline 48 & Green bee-eater & Merops orientalis & - & $\checkmark$ & - & $\mathrm{R}$ \\
\hline 49 & Green sandpiper & Tringaochropus & $\checkmark$ & - & - & $\mathrm{R}$ \\
\hline 50 & $\begin{array}{l}\text { Green-billed } \\
\text { malkoha }\end{array}$ & Phaenicophaeus tristis & - & $\checkmark$ & - & $\mathrm{M}$ \\
\hline 51 & Grey backed shrike & Lanius tephronotus & - & $\checkmark$ & - & $\mathrm{M}$ \\
\hline 52 & Grey bushchat & Saxicola ferreus & - & $\checkmark$ & - & $\mathrm{R}$ \\
\hline 53 & Grey treepie & Dendrocitta formosae & - & $\checkmark$ & - & $\mathrm{R}$ \\
\hline 54 & Grey wagtail & Motacilla cinerea & $\checkmark$ & - & - & $\mathrm{V}$ \\
\hline
\end{tabular}


Forestry Journal of Institute of Forestry, Nepal Issue No. 17 Bajagain, Pokhrel, Baniya, Pradhan, Paudel and Joshi

\begin{tabular}{|c|c|c|c|c|c|c|}
\hline 55 & $\begin{array}{l}\text { Grey-breasted } \\
\text { prinia }\end{array}$ & Prinia hodgsonii & $\checkmark$ & - & - & $\mathrm{R}$ \\
\hline 56 & $\begin{array}{l}\text { Grey-capped pigmy } \\
\text { woodpecker }\end{array}$ & Dendrocopos canicapillus & $\checkmark$ & - & - & $\mathrm{R}$ \\
\hline 57 & $\begin{array}{l}\text { Grey-headed } \\
\text { woodpecker }\end{array}$ & Picus canus & - & $\checkmark$ & - & $\mathrm{R}$ \\
\hline 58 & $\begin{array}{l}\text { Grey-winged } \\
\text { blackbird }\end{array}$ & Turdus boulboul & $\checkmark$ & - & - & $\mathrm{R}$ \\
\hline 59 & $\begin{array}{l}\text { Himalayan } \\
\text { flameback }\end{array}$ & Dinopiumshorii & $\checkmark$ & - & - & $\mathrm{V}$ \\
\hline 60 & Himalayan bulbul & Pycnonotus leucogenys & $\checkmark$ & $\checkmark$ & - & $\mathrm{R}$ \\
\hline 61 & House crow & Corvus splendens & $\checkmark$ & $\checkmark$ & - & $\mathrm{R}$ \\
\hline 62 & House sparrow & Passer domesticus & $\checkmark$ & - & - & $\mathrm{R}$ \\
\hline 63 & Indian cuckoo & Cuculus micropterus & $\checkmark$ & - & - & $\mathrm{V}$ \\
\hline 64 & $\begin{array}{l}\text { Indian golden } \\
\text { oriole }\end{array}$ & Oriolus kundoo & $\checkmark$ & - & - & $\mathrm{V}$ \\
\hline 65 & Indian Jungle crow & Corvus culminatus & $\checkmark$ & - & - & $\mathrm{V}$ \\
\hline 66 & Indian pitta & Pitta brachyuran & - & $\checkmark$ & - & $\mathrm{V}$ \\
\hline 67 & Indian pond heron & Ardeola grayii & - & $\checkmark$ & - & $\mathrm{R}$ \\
\hline 68 & Indian roller & Coracias benghalensis & $\checkmark$ & $\checkmark$ & - & $\mathrm{R}$ \\
\hline 69 & Intermediate egret & Mesophoyx intermedia & - & $\checkmark$ & - & $\mathrm{M}$ \\
\hline 70 & Jungle babbler & Turdodes striata & $\checkmark$ & - & - & $\mathrm{R}$ \\
\hline 71 & Jungle myna & Acridootheres fuscus & $\checkmark$ & $\checkmark$ & - & $\mathrm{R}$ \\
\hline 72 & Jungle owlet & Glaucidium radiatum & $\checkmark$ & $\checkmark$ & - & $\mathrm{R}$ \\
\hline 73 & Large cuckoo shrike & Coracina macei & $\checkmark$ & $\checkmark$ & - & $\mathrm{R}$ \\
\hline 74 & Large-billed crow & Corvus macrorhynchos & $\checkmark$ & - & - & $\mathrm{R}$ \\
\hline 75 & $\begin{array}{l}\text { Lemon-rumped } \\
\text { leaf-warbler }\end{array}$ & Phylloscopus chloronotus & - & $\checkmark$ & - & $\mathrm{R}$ \\
\hline 76 & Lesser coucal & Centropus bengalensis & $\checkmark$ & - & - & $\mathrm{R}$ \\
\hline 77 & Lesser kestrel & Falco naumanni & $\checkmark$ & - & - & $\mathrm{V}$ \\
\hline 78 & $\begin{array}{l}\text { Lesser racket tailed } \\
\text { drongo }\end{array}$ & Dicrurusremifer & $\checkmark$ & - & - & $\mathrm{R}$ \\
\hline 79 & Lesser yellownape & Picus chlorolophus & $\checkmark$ & - & - & $\mathrm{R}$ \\
\hline 80 & Lineated barbet & Megalaima lineata & $\checkmark$ & - & - & $\mathrm{R}$ \\
\hline 81 & Little egret & Egretta gragetta & - & $\checkmark$ & - & $\mathrm{M}$ \\
\hline 82 & Little ringed plover & Charadrius dubius & - & $\checkmark$ & - & $\mathrm{R}$ \\
\hline 83 & Long-tailed minivet & Pericrocotus ethologus & $\checkmark$ & - & - & $\mathrm{R}$ \\
\hline 84 & Long-tailed shrike & Lanius schach & - & $\checkmark$ & - & $\mathrm{R}$ \\
\hline
\end{tabular}




\begin{tabular}{|l|l|l|l|l|l|l|}
\hline 85 & $\begin{array}{l}\text { Mountain hawk } \\
\text { eagle }\end{array}$ & Nisaetusnipalensis & $\checkmark$ & - & - & $\mathrm{M}$ \\
\hline 86 & Nepal house martin & Delichon nipalense & - & $\checkmark$ & - & $\mathrm{R}$ \\
\hline 87 & $\begin{array}{l}\text { Oriental honey } \\
\text { buzzard }\end{array}$ & Pernis ptilorhynchus & $\checkmark$ & - & - & $\mathrm{R}$ \\
\hline 88 & $\begin{array}{l}\text { Oriental magpie } \\
\text { robin }\end{array}$ & Copsychus saularis & $\checkmark$ & - & - & $\mathrm{R}$ \\
\hline 89 & Oriental turtle dove & Streptopelia orientalis & $\checkmark$ & $\checkmark$ & - & $\mathrm{R}$ \\
\hline 90 & Oriental white eye & Zosterops palpebrosus & $\checkmark$ & - & - & $\mathrm{R}$ \\
\hline 91 & Paddyfield pipit & Anthus rufulus & - & $\checkmark$ & - & $\mathrm{R}$ \\
\hline 92 & Peregrine falcon & Falco peregrinus & $\checkmark$ & - & - & $\mathrm{V}$ \\
\hline 93 & Pied bushchat & Saxicola caprata & - & $\checkmark$ & - & $\mathrm{R}$ \\
\hline 94 & Pied kingfisher & Cerylerudis & - & $\checkmark$ & - & $\mathrm{R}$ \\
\hline 95 & Plain martin & Riparia paludicola & - & $\checkmark$ & - & $\mathrm{R}$ \\
\hline 96 & Plain prinia & Prinia inornata & - & $\checkmark$ & - & $\mathrm{R}$ \\
\hline 97 & $\begin{array}{l}\text { Plum-headed } \\
\text { parakeet }\end{array}$ & Psittacula cyanocephala & $\checkmark$ & $\checkmark$ & - & $\mathrm{V}$ \\
\hline 98 & Purple sunbird & Nectarinia asiatica & $\checkmark$ & - & - & $\mathrm{R}$ \\
\hline 99 & $\begin{array}{l}\text { Red- billed blue } \\
\text { magpie }\end{array}$ & Urocissa erythroryncha & $\checkmark$ & $\checkmark$ & - & $\mathrm{R}$ \\
\hline 100 & Red-napped ibis & Pseudibis papilllosa & $\checkmark$ & - & - & $\mathrm{V}$ \\
\hline 101 & $\begin{array}{l}\text { Red-rumped } \\
\text { swallow }\end{array}$ & Cecropis daurica & - & $\checkmark$ & - & $\mathrm{R}$ \\
\hline 102 & Red-vented bulbul & Pycnonotus cafer & $\checkmark$ & $\checkmark$ & - & $\mathrm{R}$ \\
\hline 103 & $\begin{array}{l}\text { Red-wattled } \\
\text { lapwing }\end{array}$ & Vanellus indicus & - & $\checkmark$ & - & $\mathrm{R}$ \\
\hline 104 & Richard's pipit & Anthus richardi & - & $\checkmark$ & - & $\mathrm{V}$ \\
\hline 105 & River lapwing & Vanellus duvaucelii & - & $\checkmark$ & - & $\mathrm{R}$ \\
\hline 106 & $\begin{array}{l}\text { Rose-ringed } \\
\text { parakeet }\end{array}$ & Psttacula krameri & $\checkmark$ & $\checkmark$ & - & $\mathrm{R}$ \\
\hline 107 & Rosy pipit & Anthus roseatus & - & $\checkmark$ & - & $\mathrm{M}$ \\
\hline 108 & Ruddy shelduck & Tadorna ferruginea & - & $\checkmark$ & - & $\mathrm{V}$ \\
\hline 109 & Rufous treepie & Dendrocitta vagabunda & $\checkmark$ & - & - & $\mathrm{R}$ \\
\hline 110 & Rufous woodpecker & Celeus brachyurus & $\checkmark$ & - & - & $\mathrm{R}$ \\
\hline 111 & Scaly thrush & Zoothera dauma & $\checkmark$ & - & - & $\mathrm{M}$ \\
\hline 112 & $\begin{array}{l}\text { Scaly-breasted } \\
\text { munia }\end{array}$ & Lonchura punctulata & - & $\checkmark$ & - & $\mathrm{R}$ \\
\hline 113 & Scarlet minivet & Pericrocotus speciosus & $\checkmark$ & - & - & $\mathrm{R}$ \\
\hline 114 & Shikra & - & $\checkmark$ & - & $\mathrm{R}$ \\
\hline
\end{tabular}


Forestry Journal of Institute of Forestry, Nepal Issue No. 17 Bajagain, Pokhrel, Baniya, Pradhan, Paudel and Joshi

\begin{tabular}{|c|c|c|c|c|c|c|}
\hline 115 & $\begin{array}{l}\text { Short-toed snake } \\
\text { eagle }\end{array}$ & Circaetus gallicus & - & $\checkmark$ & - & $\mathrm{M}$ \\
\hline 116 & Small pratincole & Glareola lacteal & $\checkmark$ & $\checkmark$ & - & $\mathrm{M}$ \\
\hline 117 & Spangled drongo & Dicrurus hottentottus & $\checkmark$ & - & - & $\mathrm{R}$ \\
\hline 118 & Spotted dove & Stigmatopelia chinensis & $\checkmark$ & - & - & $\mathrm{R}$ \\
\hline 119 & Spotted owlet & Athene brama & $\checkmark$ & $\checkmark$ & - & $\mathrm{R}$ \\
\hline 120 & Steppe eagle & Aquila nipalensis & - & $\checkmark$ & EN & $\mathrm{V}$ \\
\hline 121 & Verditer flycatcher & Eumyias thalassinus & $\checkmark$ & $\checkmark$ & - & $\mathrm{M}$ \\
\hline 122 & $\begin{array}{l}\text { Western yellow } \\
\text { wagtail }\end{array}$ & Motacilla flava & - & $\checkmark$ & - & $\mathrm{V}$ \\
\hline 123 & $\begin{array}{l}\text { White- breasted } \\
\text { waterhen }\end{array}$ & Amaurornis phoenicurus & - & $\checkmark$ & - & $\mathrm{R}$ \\
\hline 124 & $\begin{array}{l}\text { White throated } \\
\text { kingfisher }\end{array}$ & Halcyon smyrnensis & - & $\checkmark$ & - & $\mathrm{R}$ \\
\hline 125 & White wagtail & Motacilla alba & - & $\checkmark$ & - & M \\
\hline 126 & $\begin{array}{l}\text { White-bellied } \\
\text { drongo }\end{array}$ & Dicrurus caerulescens & $\checkmark$ & - & - & $\mathrm{R}$ \\
\hline 127 & $\begin{array}{l}\text { White-browed } \\
\text { wagtail }\end{array}$ & Motacilla maderaspatensis & - & $\checkmark$ & - & $\mathrm{R}$ \\
\hline 128 & $\begin{array}{l}\text { White-capped } \\
\text { water-redstart }\end{array}$ & $\begin{array}{l}\text { Chaimarrornis } \\
\text { leucocephalus }\end{array}$ & - & $\checkmark$ & - & $\mathrm{R}$ \\
\hline 129 & $\begin{array}{l}\text { White- } \\
\text { rumpedshama }\end{array}$ & Copsychus malabaricus & - & $\checkmark$ & - & $\mathrm{R}$ \\
\hline 130 & $\begin{array}{l}\text { White-throated } \\
\text { fantail }\end{array}$ & Rhipidura albicollis & - & $\checkmark$ & - & $\mathrm{R}$ \\
\hline 131 & $\begin{array}{l}\text { Yellow wattled } \\
\text { lapwing }\end{array}$ & Vanellus malabaricus & - & $\checkmark$ & - & $\mathrm{R}$ \\
\hline 132 & Zitting cisticola & Cisticola juncidis & - & $\checkmark$ & - & $\mathrm{R}$ \\
\hline
\end{tabular}

